\title{
Effect of Carburizing Temperature and Holding Time on Mechanical Properties Low Carbon Steel Using Schleichera Oleosa Carbonized Chorcoal
}

\author{
Agustinus Deka Betan ${ }^{1}$, Melsiani R.F. Saduk ${ }^{1}$, Fransisko Piri Niron ${ }^{1}$, Irene Budayawati ${ }^{1}$ \\ \{agustinusbetan@gmail.com, melsianisd@gmail.com, fransiskoniron@yahoo.co.id, \\ irenebudayawati26@gmail.com\} \\ Department of Mechanical Engeering, State Polytechnic Kupang ${ }^{1}$
}

\begin{abstract}
The sloping fastening bolt on the lathe functions to connect the top slide component with the carriage mechanically. Damage to the bolt is more due to the accumulation of cutting forces that occur. To prepare spare parts in accordance with the specifications of the mechanical properties of the original bolt lathe needs to be done research. Low carbon steel was chosen as an alternative for making bolts for the replacement of component parts from the Harison T 300 lathe. Improved mechanical properties of low carbon steel carried out the carbonization process of schleichera oleosa charcoal with a holding time of 1 hour, 1.5 hours, 2 hours using a temperature variation of $800^{\circ} \mathrm{C}, 850^{\circ} \mathrm{C}, 900^{\circ} \mathrm{C}$ in water and oil quenching. Experimental results prove that the best shear strength occurs at a temperature of $800^{\circ} \mathrm{C}$, withstands 1 hour with quenching of used oil of $11396 \mathrm{~N} / \mathrm{mm}^{2}$.
\end{abstract}

Keywords: Carburizing, Temperature, Shear Strength, Schleichera Oleosa Charcoal

\section{Introduction}

The Harison T300 lathe is one of the types of lathes in the Kupang State Polytechnic and has been operated since 1988 for student practicum activities. From the results of observation in the Mechanical Technology Laboratory it is known that the bolt component in the slurry has failed (broken). To replace the original bolt parts needs to be done research in order to obtain the desired mechanical properties such as shear strength, hardness.

Selection of carbon steel as an alternative material for the replacement of the slurry bolt on the lathe. The reason for using carbon steel is because this steel is found in the market with variations in strength that vary according to the content of the existing carbon content. In this research, a low carbon steel alternative material for the replacement of the sloping bolt is used. Several studies that have been carried out in connection with the carburizing process such as The result observed that the mechanical properties of mild steels were found to be strongly influenced by the process of carburization, carburizing temperature and soaking time at carburizing temperature. It was concluded that the optimum combination of mechanical properties is achieved at the carburizing temperature of $900{ }^{\circ} \mathrm{C}$ followed by oil quenching and tempering at $550{ }^{\circ} \mathrm{C}$. Gunawan [1] examined the mechanical and microstructure properties of St 41 carbon steel by carburizing pack methods with temperatures of $650{ }^{\circ} \mathrm{C}, 750{ }^{\circ} \mathrm{C}$ and 850 ${ }^{\circ} \mathrm{C}$ with a holding time of 30 minutes. The carbonation process uses coconut shell charcoal powder mixed with $25 \% \mathrm{BaCO} 3$ as a catalyst and then dipped in a water cooling medium. The 
results showed a temperature of $850{ }^{\circ} \mathrm{C}$ produced the highest surface strength of $324 \mathrm{HV}$. Ihom et al. [2] revealed that the waste organic materials used in the case hardening media all showed improvement in the hardness values of the mild steel specimens over the $30 \mathrm{HRC}$ hardness value of the untreated mild steel specimen. Abdulrazaaq [3] in an experimental work shows that at carburizing temperature $\left(850^{\circ} \mathrm{C}\right)$, the hardness was increases from the inside to outside of specimen from (102 to HV 250), while increases for temperatures $\left(900^{\circ} \mathrm{C}\right)$. Min S. Htun et al. [4] found that mechanical properties of selective alloy were significantly changed by temper treatment. By increasing the tempering time and temperature, hardness and ultimate tensile strength are gradually decreased and ductility was improved. Olanike et al. [5] concluded that the optimum combination of mechanical properties is achieved at the carburizing temperature of $950^{\circ} \mathrm{C}$ soaked for 120 minutes followed by oil quenching and tempered at $500^{\circ} \mathrm{C}$ for 60 minutes.

\section{Material and Method}

Test specimens using low carbon steel material with the data in Table $\mathbf{1 .}$

Table 1. Chemical Composition of Low Carbon Steel (St 37)

\begin{tabular}{ll}
\hline Element & \% Chemical Composition \\
\hline Iron $(\mathrm{Fe})$ & 78,65 \\
Carbon $(\mathrm{C})$ & 0,12 \\
Silicon $(\mathrm{Si})$ & 0,11 \\
Sulfur $(\mathrm{S})$ & 0,012 \\
Manganese (Mn) & 0,30 \\
Phospor (P) & 0,13 \\
\hline
\end{tabular}

\subsection{Making Spesimen and Carbon}

The M8 bolt specimen was made of solid St 37 material in the form of $\varnothing 20 \mathrm{~mm}$. The material is then turned into a M8 bolt on a Pinocho type lathe (Figure 1). The activated carbon material used for carburizing is schleichera oleosa charcoal powder then filtered with a size of $0.65 \mathrm{~mm}$ (Figure. 2)

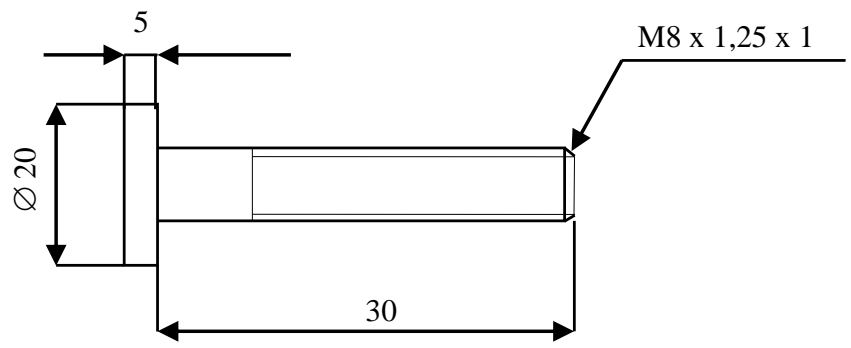

Figure 2. Shear Test Spesimen 


\subsection{Pack Carburizing Operation}

Turning bolt M8 specimens are then bound to form a bundle to facilitate the process of taking from the cementation box. Carbon for carburizing comes from finely schleichera oleosa charcoal with a grain size of $0.6 \mathrm{~mm}$. Turn on the heating oven and put the cementation box into the furnace and then close it. Perform temperature settings of $800{ }^{\circ} \mathrm{C}, 850{ }^{\circ} \mathrm{C}$ and $900{ }^{\circ} \mathrm{C}$. The carburizing process is carried out with holding timel adjusted for the test variable. The stages of the carburizing test for the M8 bolt by inserting cementation boxes containing 2 bundles of specimens that have been covered with 0.86 gram of carbon fiber into the heating furnace and then adjusting the temperature of $800^{\circ} \mathrm{C}$. If the heating temperature of the specimen has reached $800^{\circ} \mathrm{C}$ then the holding time process continues for 1 hour. After holding time is reached, open the lid of the heating furnace and lift the specimen 1 bundle to put it in water cooling and the other to oil coolers.

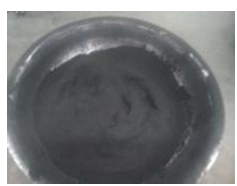

Figure 2. Schleichera Oleosa Charcoal Powder

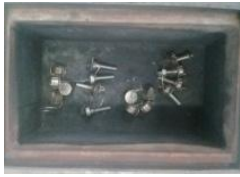

Figure 3. Specimen in the cementation box

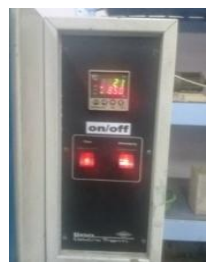

Figure 4. Heating Furnace

\subsection{Mechanical Testing}

Carburizing M8 bolt testing is carried out at room temperature with mechanical properties to be tested is the shear strength. Shear testing is carried out with an engineering shear test of the connection between the plates with the tensile test principle. The strain rate given during the shear testing process is $10^{-3} / \mathrm{s}$. To prove the accuracy of the data, the shear test repeats were carried out in 4 specimens.

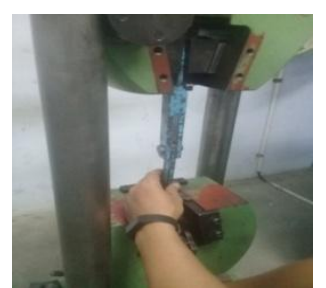

Figure 5. Shear Test Machine Tarno Grocki

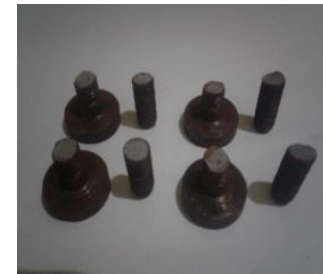

Figure 6. Specimen Shear Test 


\subsection{Result and Discussion}

From the results of the next shear test with calculations to determine the shear strength. the influence of temperature and holding time can be seen in Figure 7. The shear strength at all variations in room temperature is illustrated in Figure 7. From the figure, it can be seen that there is a difference in the shear strength of carburizing results when compared to the shear strength of low carbon steel before carburizing.

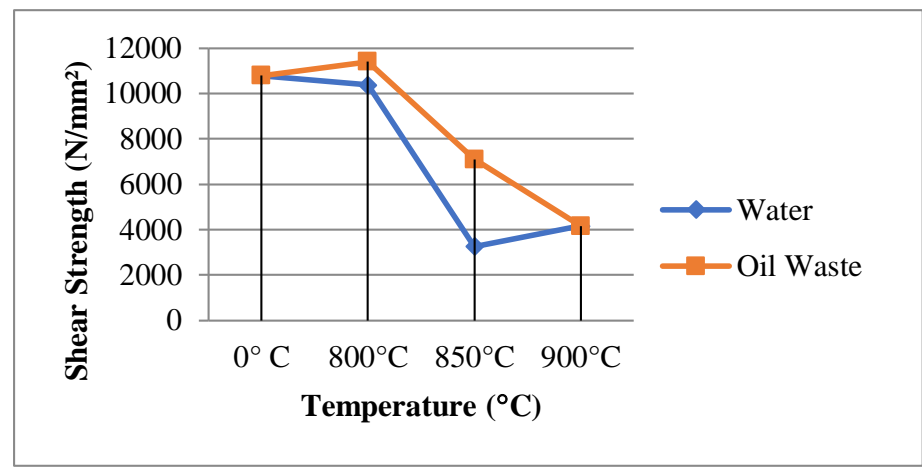

Figure 7. Effect of Temperature and Quenching on the Shear Strength of the Sample

In Figure 7. carburizing process with temperature and guenching variables has a great influence on shear strength. For quenching oil waste shows a decrease in shear strength when the temperature is greater. At a temperature of $800{ }^{\circ} \mathrm{C}$ with oil waste guenching produces the highest shear strength of $11396 \mathrm{~N} / \mathrm{mm}^{2}$. The lowest shear strength occurs at a temperature of $900^{\circ} \mathrm{C}$ with a value of $4184 \mathrm{~N} / \mathrm{mm}^{2}$. While quenching water is different from oil waste where the shear stress strength experiences ups and downs when the greater the carburizing temperature. At $800^{\circ} \mathrm{C}$ water quenching shows a shear strength of $10384 \mathrm{~N} / \mathrm{mm}^{2}$. For the temperature of $850^{\circ} \mathrm{C}$, the shear strength decreased with a value of $3256 \mathrm{~N} / \mathrm{mm}^{2}$ and at a temperature of $900^{\circ} \mathrm{C}$ the shear strength increased again by $4165 \mathrm{~N} / \mathrm{mm}^{2}$.

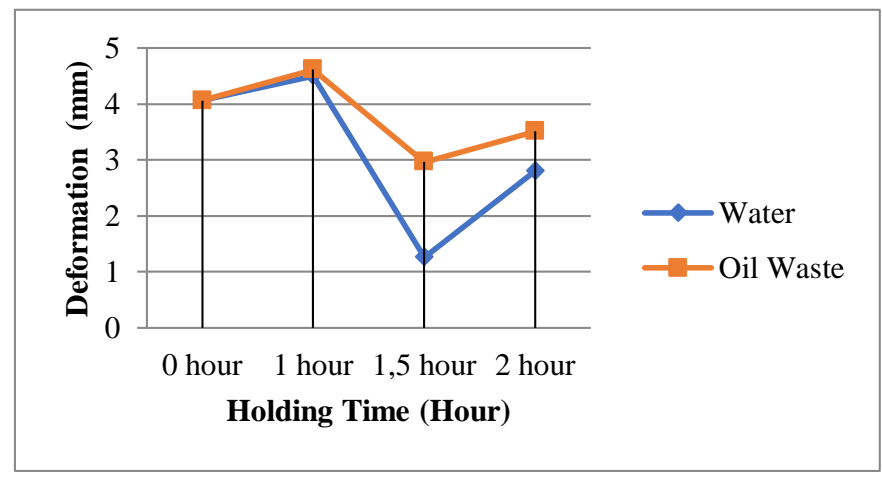

Figure 8. Effect of Holding Time and Quenching on the Deformation of Sample 
Figure 8. Shows deformation changes due to samples given different holding times and quenching. In general, the results of carburizing samples show changes in the erratic deformation for each quenching. The best strength value is shown by oil guenching at a holding time of 1 hour with a deformation change of $4.61 \mathrm{~mm}$. Deformation changes due to holding time variations are seen up and down where oil quenching at 1.5 hour holding time decreases the deformation value to $2.96 \mathrm{~mm}$ and increases again to $3.51 \mathrm{~mm}$ at 2 hour holding time. While deformation of water quenching is $4.5 \mathrm{~mm}$ with a holding time of 1 hour but in holding time 1.5 hours only gets $1.26 \mathrm{~mm}$ and then increases again to $2.8 \mathrm{~mm}$ at a holding time of 2 hours.

\section{Conclusions}

The following conclusions can be drawn from the results of the discussion that schleichera oleosa charcoal as active carbon is an alternative to increase the strength of low carbon steel material by providing variations in temperature and holding time.

\section{Acknowledgement}

At the end of this article, the authors should express his gratitude to the lecturers and educators who have given the opportunity to conduct research in Malang State Polytechnic.

\section{References}

[1] Edy Gunawan., Analysis of Temperature Effect on Mechanical Properties and Micro Sructure in Low Carbon Steel (St 41) with Pack Carburizing Method. Engineering and Science Journal ISSN 2579-5422 online. ISSN2580 - 4146. Volume 1, Number 2, December 2017, 117124

[2] Ihom A. P., Nyior G. B., Alabi O. O., Segun S., Nor I. J., Ogbodo J. N., The potentials of waste organic materials for surface hardness improvement of mild steel, International Journal of Scientific and Engineering Research, 2012, 3(11), p.1-20.

[3] Mohammed A. Abdulrazzaq, 2015. Investigation The Mechanical Properties of Carburized Low Carbon Steel. Journal of Engineering Research Application. ISSN: 2248 - 9622. Vol 6. Issue 9.(part-2) September 2016,pp 59 - 66.

[4] Min S. Htun, Si T. Kyaw, Kay T. Lwin, 2008. Effect of Heat Treatment on Microstructures and Mechanical Properties of Spring Steel. Journal of Metals, Materials and Minerals, Vol.18 No.2 pp.191-197.

[5] Olanike M. O., Samuel R. Oke., Iyiola O. Otunniyi, Fatai O. Aramide., 2015. Effect of carburizing temperature and time on mechanical properties of AISI/SAE 1020 steel using carbonized palm kernel shell. Leonardo Electronic Journal of Practices and Technologies ISSN 1583-1078. Issue 27, July-December 2015p. 41-56. 